\title{
Sistem Noken Berbasis Hukum Progresif dalam Bingkai Demokrasi di Indonesia
}

\author{
Wiwit Pratiwi \\ Sugiarto \\ Marlina \\ Fakultas Hukum Universitas Prof. Hazairin, SH.,MH., Bengkulu \\ Email Korespondensi : wpratiwi170993@gmail.com
}

\begin{abstract}
This research is focused on the issue of the electoral system which uses the adat mechanism namely the noken system implemented by the indigenous Papuan people in Indonesia. By using normative legal research methods in the form of library research conducted by collecting primary, secondary and tertiary legal materials. In this study there are several approaches used, namely the law approach, historical approach, case approach. Material collection is done by collecting and analyzing library materials and related documents. Furthermore, the data were analyzed qualitatively and inductively juridically by interpreting and constructing statements contained in documents and legislation with. To classify legal materials, the authors use content analysis. This study concludes that the electoral system in Indonesia adheres to the principle of direct, general, free, confidential, honest and fair as mandated by Article 22E of the 1945 Constitution of the Republic of Indonesia. However, the noken system is contrary to the principle of election, so there is a conflict between the systems elections in general with the Noken system and the idea of progressive law are the answer to these contradictions.
\end{abstract}

Keywords: adat, progressive law, noken, electoral system.

\begin{abstract}
ABSTRAK
Penelitian ini difokuskan pada persoalan sistem pemilu yang menggunakan mekanisme adat yaitu sistem noken yang dilaksanakan masyarakat adat Papua di Indonesia. Dengan menggunakan metode penelitian hukum normatif yaitu berupa penelitian kepustakaan yang dilakukan dengan mengumpulkan bahan hukum baik primer, sekunder dan atau tersier. Di dalam penelitian ini terdapat beberapa pendekatan yang digunakan yaitu pendekatan undang-undang, pendekatan historis, Pendekatan kasus. Pengumpulan bahan dilakukan dengan mengumpulkan dan menganalisis bahanbahan keperpustakaan serta dokumen-dokumen yang berkaitan. Selanjutnya, data dianalisis secara yuridis kualitatif dan induktif dengan jalan menafsirkan dan mengkonstruksikan pernyataan yang terdapat dalam dokumen dan perundang-undangan dengan. Untuk melakukan klasifikasi bahan-bahan hukum, penulis menggunakan analisis isi. Penelitian ini menyimpulkan bahwa Sistem pemilu di Indonesia menganut asas langsung, umum, bebas, rahasia, jujur dan adil seperti yang diamanatkan Pasal 22E Undang-Undang Dasar Negara Republik Indonesia Tahun 1945. Namun sistem noken bertentangan dengan asas pemilu, sehingga terjadi pertentangan antara sistem pemilu pada umumnya dengan sistem noken. Gagasan mengenai hukum progresif menjadi jawaban dari pertentangan tersebut
\end{abstract}

Kata kunci: adat, hukum progresif, noken, sistem pemilihan umum. 


\section{Pendahuluan}

Di Indonesia wujud demokrasi itu diwujudkan melalui Pemilihan umum Presiden dan Wakil Presiden. Pemilu diselenggarakan dengan tujuan untuk memilih wakil rakyat dan wakil daerah, serta untuk membentuk pemerintahan yang demokratis, kuat, dan memperoleh dukungan rakyat dalam rangka mewujudkan tujuan nasional sebagaimana Undang-Undang Dasar Negara Republik Indonesia Tahun 1945. Pemilu dilaksanakan oleh negara Indonesia dalam rangka mewujudkan kedaulatan rakyat sekaligus penerapan prinsip-prinsip atau nilainilai demokrasi, meningkatkan kesadaran politik rakyat untuk berpartisipasi aktif dalam pemilihan umum demi terwujudnya cita-cita masyarakat Indonesia yang demokratis.

Pada Pemilu Presiden dan Wakil Presiden April 2019 lalu, masyarakat di Papua terlibat dalam Pemilu, namun dalam pelaksanaanya disesuaikan dengan mekanisme adat. Pencoblosan kertas suara diwakilkan kepada kepala-kepala suku. Pencoblosan tidak dilakukan di dalam bilik suara dan kertas suara yang sudah dicoblos tersebut tidak dimasukkan ke dalam kotak suara, tapi dimasukkan ke dalam tas khas orang Papua yang disebut " Noken". Tata cara yang demikian ini dikenal dengan sistem noken yang merupakan sistem pemilihan secara adat.

Sejak nama calon Presiden dan Wakil Presiden diketahui, orang Papua di berbagai kampung di pergunungan mulai terlibat dalam diskusi-diskusi, baik yang terjadi secara spontan maupun terencana. Diskusi dilakukan dirumah adat, halaman tempat ibadah, halaman balai desa atau halaman rumah tertentu, dan dipimpin oleh tokoh agama, tokoh pemuda, guru atau pegawai negeri yang dipercayai oleh penduduk lokal. Dalam diskusi itu, mereka saling berbagi informasi tentang sepak terjang setiap calon yang hendak dipilih. Dengan mendapatkan informasi yang sebanyak-banyaknya, orang kampung mulai mendapat gambaran tentang calon siapa yang dapat dipercaya dan layak dipilih. Kemudian calon pilihannya disampaikan kepada orang lain untuk menguji kelayakan dan mendapatkan tanggapan balik. Dengan demikan, semua calon yang disebutkan para pemilih diuji kelayakannya oleh masyarakat dengan menggunakan kriteria kultural. Pengujian melalui diskusi berlangsung hingga para pemilih disuatu desa mencapai kesepakatan. Isi kesepakatan mencakup calon yang dapat dipercayai dan karena itu, layak diberikan kepadanya, serta seberapa banyak suara yang dapat dialokasikan baginya. ${ }^{1}$

Dalam sistem noken di Papua, kesepakatan rakyat ditetapkan sebelum pemungutan suara dilaksanakan. Mereka tidak merahasiakan kesepakatan mereka tentang calon yang

\footnotetext{
${ }^{1}$ http://indonesiasatu.kompas.com/read/2014/08/21/17470521/Sistem.Noken.dan.Demokrasi. diakses pada
} Kamis, 11 September 2014, pukul 21.00 WIB. 
mereka pilih. Mereka malah menceritakan kesepakatan mereka ke orang lain. Oleh karena itu, biasanya orang sudah tahu hasil pemilu atau calon siapa yang akan dipilih oleh masyarakat di desa sebelum pemungutan suara dilaksanakan. Pada hari pemungutan suara masyarakat hanya mengungkapkan kesepakatan mereka. Pemilihan dengan sistem noken ini telah mendapatkan legitimasi dari Mahkamah Konstitusi (MK) sebagaimana termuat dalam pertimbangan hukum Mahkamah dalam Putusan MK Nomor 47-81/PHPU.A-VII/2009, tanggal 9 Juni 2009 pada paragraf yang antara lain menyatakan:

"Menimbang bahwa Mahkamah dapat memahami dan menghargai nilai budaya yang hidup dikalangan masyarakat Papua yang khas dalam menyelenggarakan pemilihan umum dengan cara atau sistem 'kesepakatan warga' atau 'aklamasi'. Mahkamah menerima cara pemilihan kolektif (kesepakatan warga atau aklamasi) yang telah diterima masyarakat Yahukimo tersebut karena jika dipaksakan pemilihan umum sesuai dengan peraturan perundang-undangan yang berlaku dikhawatirkan akan timbul konflik diantara kelompok-kelompok masyarakat setempat".

Kemudian diperkuat dengan aturan yang dibuat KPU yaitu berdasarkan PKPU Nomor 810/PL.02.6-Kpt/06/KPU/IV/2019 tentang Pedoman Pelaksanaan Pemungutan Suara Menggunakan Sistem Noken/Ikat di Papua dalam Pemilu 2019, kabupaten yang masih menggunakan sistem noken ada 12 kabupaten dari 14 kabupaten yang berada di wilayah pegunungan tengah.

Di Indonesia sistem pemilu sebagai manifestasi demokrasi dapat lebih efektif , efisien, dan harus memenuhi asas langsung, umum, bebas, rahasia, jujur, dan adil (luber-jurdil). ${ }^{2}$ Penerapan Asas ini bertujuan untuk mewujudkan Pemilu yang lebih demokratis dan berkualitas. Pemilu yang lebih demokratis dilaksanakan dengan sistem pemilu secara langsung. ${ }^{3}$ Ini merupakan hasil unifikasi (penyeragaman) hukum dalam penyelenggaraan pemilu secara nasional sebagai bagian dari sistem ketatanegaraan. Oleh karena itu, pemilihan umum melalui sistem noken masih menjadi problematika dan pro-kotra dalam bingkai demokrasi Indonesia sehingga sistem noken ini menarik dibahas ditengah gejolak politik di Indonesia.

Menurut Reydonnyzar, apabila masing-masing dari daerah/suku tetap mempertahankan cara-cara kedaerahan dan kesukuan dalam pemilu, dapat dibayangkan jika 1.127 suku di Indonesia melaksanakan sistem sesuai adat istiadatnya, tentu saja akan menimbulkan berbagai macam persoalan kompleks dalam pelaksanaan pemilu. Oleh karena itu, pelaksaanaan pemilu yang bercorak kedaerahan hendaknya segera diseragamkan sesuai dengan sistem yang berlaku secara nasional. ${ }^{4}$

\footnotetext{
${ }^{2}$ Moh. Mahfud MD, Politik Hukum di Indonesia, Edisi Revisi, Jakarta: Rajagrafindo Persada, 2009, hlm. 249.

${ }^{3}$ H. Rozali Abdullah, Pelaksanaan Otonomi Luas Dengan Pemilihan Kepala Daerah Secara Langsung, Jakarta: Rajagrafindo Persada, 2005, hlm. 119.

http://m.hukumonline.com/berita/baca/1t5368d22e8f65a/pemerintah-anggap-sistem-noken-bertentangandengan-asas-pemilu. diakses pada Kamis, 11 September 2014, pukul 22.00 WIB.
} 
Dengan demikian, walaupun Mahkamah Konstitusi sudah menyatakan sistem noken diakui, namun ini masih menjadi problematika, karena sistem noken belum memenuhi asas pemilu yaitu, asas langsung, umum, bebas, rahasia, jujur, dan adil (luber-jurdil) . Sehingga mengenai sistem pemilihan umum dengan sistem noken ini harus dikaji secara progresif.

Berdasarkan latar belakang tersebut di atas, maka penulis tertarik untuk melakukan kajian dalam penulisan dengan judul "Sistem Noken Berbasis Hukum Progresif dalam Bingkai Demokrasi di Indonesia”.

\section{Metode Penelitian}

Penelitian ini merupakan jenis penelitian hukum normatif yang dilengkapi dengan wawancara. Data yang digunakan adalah data sekunder yang terdiri dari bahan hukum primer, sekunder dan tersier. Pengumpulan data dilakukan dengan cara dokumentasi bahan-bahan hukum primer, sekunder dan tersier, serta wawancara dengan narasumber juga dilakukan dan digunakan sebagai salah satu bahan hukum sekunder.

Analisis data merupakan tindak lanjut proses pengolahan data setelah data terkumpul. Analisis terhadap data sekunder yang didapatkan dari penelitian hukum normatif yang dilakukan dengan penelitiann kepustakaan dilakukan dengan metode deduktif sebagai pegangan utama dan metode induktif sebagai metode penunjang. Analisis terhadap data sekunder dilakukan dengan menggunakan pendekatan perundang-undangan. Data relevan dianalisis secara kualitatif. Data yang terkumpul dan disusun dan dianalisis secara sistematis. Hasil analisis berupa gambaran yang meliputi isi dan struktur hukum positif yang menjadi rujukan penyelesaian permasalahan hukum yang menjadi objek penelitian. Kemudian penyajian data dilakukan dengan menggunakan logika deduktif/induktif (umumkhusus/khusus-umum) dan kemudian dicari hubungan logis antara aspek-aspek yang saling berhubungan. Proses analisis data menggunakan metode kualitatif, dengan menganalisis datadata berupa dokumen, peraturan-peraturan, teori-teori terkait yang menghasilkan data deskriptif-analitis.

\section{Analisis dan Pembahasan}

\section{Sistem Noken Ditinjau Dari Prinsip Demokrasi}

Demokrasi merupakan pemerintahan yang berorientasi dasar kepada kepentingan rakyat. Pemerintahan yang meletakan rakyat sebagai basis epistemologis kekuasaan, sehingga tidak ada kekuasaan tanpa kehadiran rakyat. Rakyat adalah yang menentukan kenapa kekuasaan itu ada, beroperasi dan memiliki legitimasi. Demokrasi meletakkan rakyat sebagai "berhala sosial” yang menjadi basis dasar kenapa ia harus ada, bagaimana ia 
berkuasa, dengan cara apa ia menjalankan kekuasaan. ${ }^{5}$ Demokrasi sebagai sistem pemerintahan yang paling cocok dengan umat manusia telah di-amini oleh banyak kalangan. Karena salah satu faktor penting dari sistem ini adalah memposisikan individu sebagai instrumen tunggal yang bebas, merdeka dan sebagai "subyek". Ada dua kategori individu dalam posisinya sebagai subyek dalam demokrasi, yakni: ${ }^{6}$

Pertama, individu sebagai subyek individual. Sebagai subyek individual, seseorang memiliki hak asasi manusia yang dijamin universial untuk melakukan apa saja, bertindak apa saja dan mengikutib “ kehendak alamiah"nya sebagai manusia. Tidak satu orang atau satu entitas yang berhak menghalangi posisi individu sebagai subyek ini, sehingga Tuhan si "subyek" dirinya sendiri, yang mengendalikan, mengatur dan mengontrol serta mengevaluasi dirinya.

Kedua, individu sebagai subyek kolektif. Sebagai kolektivitas, individu memiliki tanggung jawab sosial. Disinilah ada pembatasan sebagai "subyek individual", ketika seseorang melebur menjadi 'subyek kolektif". Yang mengatur agar setiap subyek individu bisa hidup bersama dalam "peleburan" ke "subyek kolektif" adalah hukum yang menjamin agar hak-hak dasar individu itu bisa tetap terjaga. Dari itulah mengapa, ada demokrasi sebagai sebuah sistem. Yaitu, kehendak untuk hidup kolektif tetapi rela diatur oleh hukum supaya keamanan dan kenyaman bersama bisa tetap terjaga secara berkelanjutan.

Konsepsi demokrasi selalu menempatkan rakyat pada posisi yang sangat strategis dalam sistem ketatanegaraan, walaupun pada tatanan implementasinya terjadi perbedaan antara negara yang satu dengan negara yang lain. Karena berbagai variasi implementasi maka di dalam literature kenegaraan dikenal dengan beberapa istilah demokrasi yaitu demokrasi konstitusional, demokrasi terpimpin, demokrasi Pancasila, demokrasi rakyat, demokrasi soviet, demokrasi nasional, dan lain sebagainya. ${ }^{7}$

Di Indonesia wujud demokrasi itu diwujudkan melalui Pemilihan umum Presiden dan Wakil Presiden. Pemilu diselenggarakan dengan tujuan untuk memilih wakil rakyat dan wakil daerah, serta untuk membentuk pemerintahan yang demokratis, kuat, dan memperoleh dukungan rakyat dalam rangka mewujudkan tujuan nasional sebagaimana Undang-Undang Dasar Negara Republik Indonesia Tahun 1945. Pemilu dilaksanakan oleh negara Indonesia dalam rangka mewujudkan kedaulatan rakyat sekaligus penerapan prinsip-prinsip atau nilai-nilai demokrasi, meningkatkan kesadaran politik rakyat untuk berpartisipasi aktif dalam pemilihan umum demi terwujudnya cita-cita masyarakat Indonesia yang demokratis.

\footnotetext{
${ }^{5}$ Sarifuddin Sudding, Perselingkuhan Hukum dan Politik Dalam Negara Demokrasi, Yogyakarta: Rangkang Education, 2014, hlm 17.

${ }^{6}$ Ibid,.hlm 18.

${ }^{7}$ Moh. Koesnardi, Bintan R. Saragih, Ilmu Negara, Jakarta: Gaya Media Pratama, 1998, hlm.167.
} 
Namun dalam pelaksanaan Pemilu Presiden dan Wakil Presiden tersebut masih menjadi problematika karena masih ada daerah di Indonesia yang masih menggunakan sistem pemilihan yang dilakukan secara tradisional (kedaerahan), seperti di Papua.

Dalam pelaksanaan sistem noken masyarakat melakukan diskusi. Dalam diskusi itu, mereka saling membagi informasi tentang sepak terjang setiap calon yang hendak dipilih. Selama diskusi tersebut berlangsung, maka dilakukan pengujian hingga para pemilih di suatu desa mencapai kesepakatan. Isi kesepakatan mencakup calon yang dapat dipercayai dan, karena itu, layak diberikan suara kepadanya, serta seberapa banyak suara yang dapat dialokasikan baginya. Maka, menjadi jelas bahwa hasil pemilu adalah keputusan personal dari setiap pemilih, yang disatukan secara bersama menjadi sebuah kesepakatan komunitas, dan disimbolkan melalui noken. Rakyat melalui Ketua Adat bisa bersepakat "mengisi" semua suara dari desanya dalam sebuah noken dan menyerahkannya kepada calon yang dipercayainya atau membagi suara kepada beberapa calon.

Secara mekanisme, Sistem Pemilihan yang diterapkan masyarakat Papua dalam pemilihan Presiden dan Wakil Presiden berbeda dengan sistem pemilihan yang telah ditetapkan secara nasional. Namun dalam pemilihan model Noken ini tidak menghilangkan prinsip demokrasi karena individu dalam posisinya sebagai subyek dalam demokrasi tidak dihilangkan. Dalam hal ini (sistem noken), individu diposisikan sebagai subyek kolektif. Ada pembatasan sebagai "subyek individual", ketika seseorang melebur menjadi 'subyek kolektif". Peleburan ke subyek kolektif keamanan dan kenyaman bersama bisa tetap terjaga secara berkelanjutan. ${ }^{8}$

Hakikat dari demokrasi sebenarnya bukan terletak dari cara pemilihan (pencoblosan/pencontrengan), namun hakikat demokrasi adalah partisipasi masyarakat dalam menentukan dan ikut mengambil bagian dalam pemerintahan baik itu dilakukan secara langsung maupun tidak langasung.

\section{Sistem Noken Dalam Pemilihan Umum Presiden dan Wakil Presiden di Indonesia}

Di Papua, berlangsung pemilihan Presiden dan Wakil Presiden dengan cara yang menarik. Sebagian dari mereka memberlakukan norma lokal yang dikenal dengan istilah 'sistem noken'. Ketika komunitas memberlakukan sistem yang telah ada dalam masyarakat setempat, maka pada saat itu sebetulnya berlangsung benturan sistem. Benturan sistem ini bisa dielaborasi sebagai berikut. Sebelum mencoblos kartu suara, mereka memusyawarahkan siapa yang sebaiknya dipilih. Dalam standar kepemiluan, ini adalah

\footnotetext{
${ }^{8}$ http://budayapapua.wordpress.com/2009/06/12/noken-dan -perempuanpapua/
} 
pelanggaran. Dalam standar kepemiluan, keputusan tentang siapa yang harus dipilih adalah keputusan individual. Namun, komunitas setempat hidup dengan tradisi musyawarah, bagi mereka keputusan sepenting penentuan Presiden dan Wakil Presiden masuk dalam kategori yang harus dimusyawarahkan. Dalam proses musyawarah yang berlangsung dalam tradisi komunitas ini, tidak jarang terjadi perdebatan sengit. Ini menandakan bahwa musyawarah tidaklah sekedar kamuflase dari proses mobilisasi. Intinya, justru karena issue-nya adalah penting dalam menentukan hajat hidup mereka, issue itu harus dimusyawarahkan. Penentuan Presiden dan Wakil presiden, tentu saja memiliki implikasi publik yang serius. Mereka tidak keberatan melibatkan semua orang, namun penjaminan akan keterlibatan ini tidak harus dengan cara rahasia. Karena sudah diperdebatkan tentang keputusan yang diambil dalam komunitas itu, maka tidak ada urgensi untuk merahasiakan. Kartu suara langsung diwadahi dalam noken; tas yang terbuat dari anyaman tali. Efek dari keputusan kolektif itu akan dihadapi bersama-sama. Singkat cerita, melalui sistem noken ini mereka berhasil memenangkan tokoh yang mereka unggulkan.

Padahal untuk mencapai kualitas Pemilu yang demoktratis, Pasal 22E UUD 1945 telah menentukan asas-asas Pemilu, yaitu langsung, umum, bebas, rahasia, jujur, dan adil. Suatu Pemilu dikatakan sukses tidak hanya dilihat dari terlaksananya semua tahapan sampai terisinya jabatan Presiden dan Wakil Presiden. Tidak dapat dikatakan sebagai Pemilu yang berhasil jika mereka yang dipilih melalui cara-cara yang penuh pelanggaran dan kecurangan yang bertentangan dengan asas Luber dan Jurdil. ${ }^{9}$

Adanya Ketentuan mengenai pemilihan umum dalam UUD 1945 dimaksud untuk memberi landasan hukum yang lebih kuat bagi pemilu sebagai salah satu wahana pelaksanaan kedaulatan rakyat. Dengan adanya waktu penyelenggaraan pemilu secara teratur regular (per-lima tahun) maupun menjamin proses dan mekanisme serta penyelenggaraan pemilu yaitu langsung, umum, bebas dan rahasia (Luber), serta jujur dan adil (Jurdil). Sebagaimana maklum, pelaksanaan pemilu selama ini belum diatur dalam Undang-Undang Dasar. ${ }^{10}$

Jika dilihat dari konteks demokrasi era-sekarang dan berdasarkan asas-asas Pemilu, maka sistem noken melanggar aturan perundang-undangan karena dalam mekanisme pemilihan sistem noken, prinsip rahasia tidak lagi berlaku, karena dalam mekanismenya sebelum hari pencoblosan warga berdiskusi terlebih dahulu mengenai kadidat yang akan mereka pilih sehingga tidak ada rahasia diantara mereka. Selain itu,

\footnotetext{
${ }_{9}^{9}$ Janedjri M.Gaffar, 2013, Demokrasi dan Pemilu di Indonesia, Jakarta: Konstitusi Press (Konpress), hlm.7.

${ }^{10}$ Ni'matul Huda, 2005, Hukum Tata Negara Indonesia, Jakarta: Raja Grafindo Persada, hlm.268-269.
} 
dengan asas bebas seharusnya pemilih tidak dipaksa atau diintervensi oleh siapapun untuk memilih kandidat yang diingikannya, namun dalam sistem noken kepala suku (bigman) atau masyarakat satu dengan masyarakat lainnya dapat saling mempengaruhi.

Ada perbedaan antara pemilihan umum berdasarkan Hukum Nasional dengan pemilihan umum berdasarkan Hukum Adat (Sistem Noken), hal ini dideskripsikan sebagai berikut:

\section{Gambar 1. Mekanisme Sistem Pemilihan Umum (Hukum Nasional \& Hukum Adat) $^{11}$}
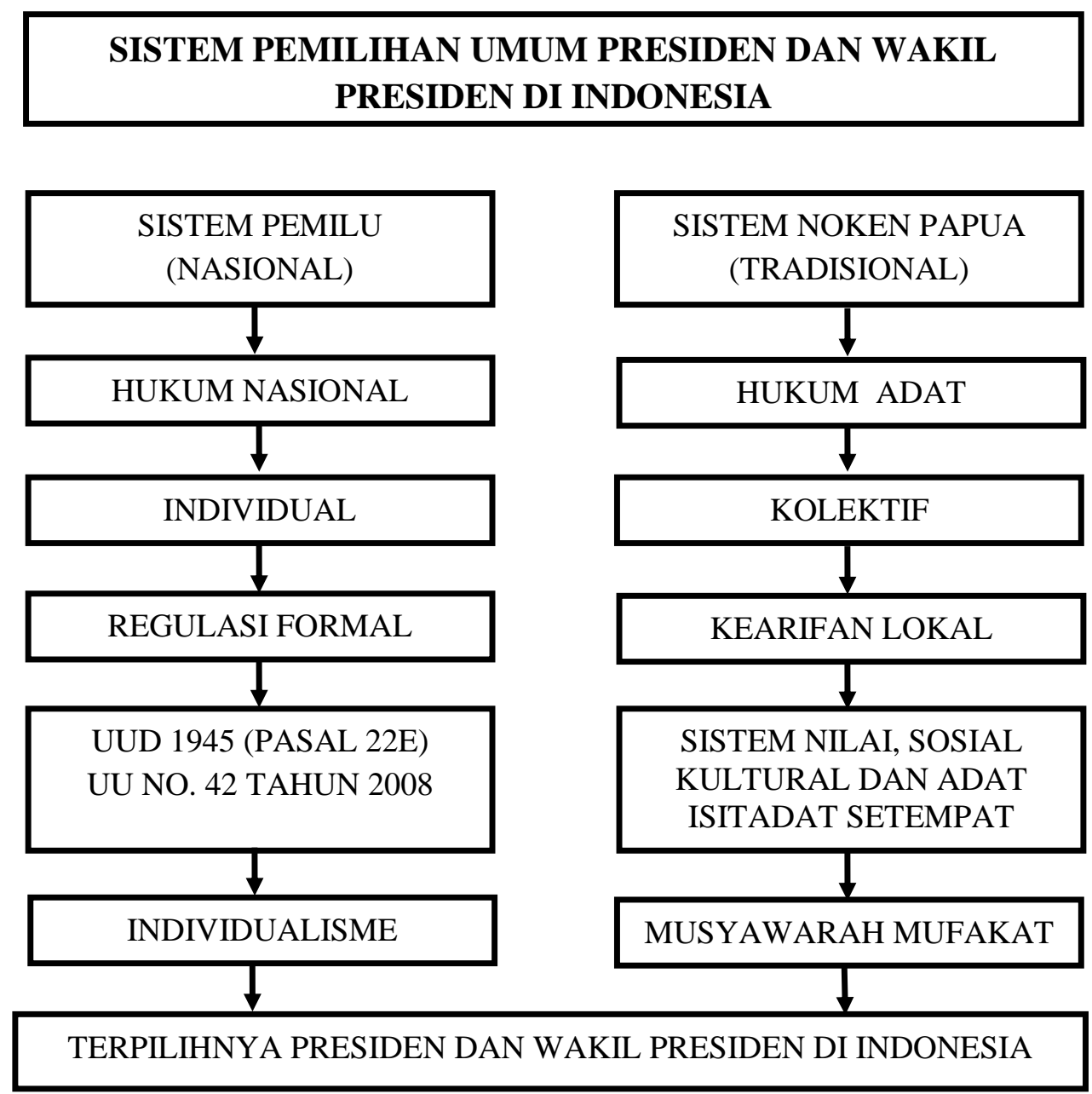

Dari skema tersebut tampak bahwa tujuan antara pemilihan umun berdasarkan hukum nasional dengan pemilihan umum berdasarkan sistem noken yang cenderung tradisional adalah sama yakni terpilihnya Presiden dan Wakil Presiden yang berkualitas secara demokratis. Namun demikian terdapat kesenjangan cara pandang yang menyebabkan benturan-benturan prinsip, argumentasi dan langkah dalam mencapai

\footnotetext{
${ }^{11}$ Hasil Olahan Penulis
}

Wiwit, Sugiarto, Marlina | Sistem Noken Berbasis Hukum Progresif dalam Bingkai Demokrasi di Indonesia 
tujuan tersebut. Pemilu secara nasional seharusnya dilakukan berdasarkan asas Langsung, umum, bebas, rahasia, jujur dan adil (Pasal 22E UUD 1945), namun disisi lain Pemilu di Papua dengan menggunakan sistem noken yang mengabaikan asas rahasia dan bebas tetapi mengutamakan musyawarah mufakat. Pemilu di Indonesia berpijak regulasi formal yang merupakan tipe hukum modern lengkap dengan ciri legalistiknya dan mekanisme yang berdasarkan peraturan perundang-undangan, sementara masyarakat adat Papua berpijak pada adat istiadat dan kearifan kultural.

Maka dengan perbedaan landasan ini terjadi kesenjangan yang akan menjadi akar fenomena konflik. Konflik yang bersumber dari kesenjangan perspektif dan perilaku berhukum tersebut yang akhirnya berimbas pada Hak Azazi Manusia. ${ }^{12}$ Prinsip-prinsip hukum progresif sepertinya cocok untuk kebutuhan menjawab mengenai petentangan ini.

Hukum Progresif itu sendiri merupakan gagasan Prof. Satjipto Rahardjo. Yang menjadi benang merah dari pemikiran hukum progresif yang digagas oleh Prof. Satjipto Rahardjo adalah: ${ }^{13}$

1. Hukum Progresif itu untuk manusia, bukan manusia untuk hukum.

2. Hukum Progresif itu harus pro-rakyat dan pro keadilan.

3. Hukum Progresif bertujuan mengantarkan manusia kepada kesejahteraan dan kebahagiaan.

4. Hukum Progresif selalu dalam proses menjadi dan dibiarkan mengalir.

5. Hukum Progresif menekankan hidup baik sebagai dasar hukum yang baik.

6. Hukum progresif memiliki tipe responsive (menolak hukum yang bersifat final dan tidak dapat digugat).

7. Hukum Progresif mendorong peran publik.

8. Hukum Progresif membangun Negara hukum yang berhati nurani.

9. Hukum Progresif dijalankan dengan kecerdasan spiritual.

10. Hukum Progresif itu merobohkan, mengganti dan membebaskan (menolak status quo dan submisif).

Bertitik tolak dari cara pandang di atas, sebenarnya ingin disandarkan disini tentang "bahaya" dari kebekuan yang sengaja dipersepsikan selalu hadir dalam setiap sisi wajah hukum. Kebekuan demikian menempatkan hukum, khususnya produk-produk legislasi dalam kedangkalan dan kemandekan makna.

Kembali ke pertentangan dalam sistem Pemilu tadi, bahwa terdapat kendala yuridis karena sistem noken tidak sejalan dengan asas Pemilu yang terdapat regulasi dan hal ini memerlukan proses rumit. Dalam penyelesaiannya menurut hukum progresif harus ditanggulangi dengan cara berhukum yang membebaskan dari belenggu positivistik yang

\footnotetext{
${ }^{12}$ Moh.Mahfud MD (et,al), Op.Cit, hlm.657.

${ }^{13}$ Ibid.,hlm.24-26
} 
sempit. Prinsip hukum progresif sebagaimana telah diuraikan diatas akan menjelaskan mengenai pertentangan tersebut.

Pertama, Hukum untuk manusia bukan manusia untuk hukum. Hukum itu tidak ada untuk dirinya sendiri, melainkan untuk sesuatu yang lebih luas, maka ketika ada masalah dalam hukum tersebut, hukumlah yang ditinjau serta diperbaiki bukan manusia yang dipaksa-paksa untuk dimasukan kedalam skema hukum. Jadi disini, ketika terjadi pertentangan, bukan manusianya yang harus masuk kedalam sistem namun sistem yang harus menyesuaikannya dengan perkembangan masyarakat. Seperti halnya sistem noken harus disesuaikan dengan kondisi masyarakat setempat.

Kedua, Regulasi dan pelaksanaannya tidak boleh bersifat kontraproduktif dalam mencapai kesejahteraan masyarakat. Pelarangan terhadap sistem noken akan berimbas pada pelanggaran Hak azazi manusia dan olehnya harus ditinjau ulang atau dilakukan terobosan untuk mengatasinya. Salah satu yang terobosan yang dapat dilakukan dengan membuat regulasi mengenai sistem noken.

Ketiga, Berhukum tidak sekedar menjalankan aturan, jika dalam mekanisme atau pelaksanaannya berbeda maka tidak serta merta masyarakat adat dianggap melanggar hukum apabila petentangan itu terjadi. Indonesia merupakan negara majemuk dan plural maka dimungkin tumbuh dan berkembang pluralisme hukum sehingga itu harus menjadi pertimbangan.

Keempat, "Adat istiadat" dalam konteks pemilihan umum Presiden dan Wakil melalui noken atau sistem noken ini tidak sekedar dimaknai sebagai wadah penyaluran kedaulatan rakyat, tetapi lebih dari itu harus dimaknai sebagai adat istiadat, budaya, hak tradisional yang harus diakui dan dihormati. Hal itu juga terakomodir di dalam Pasal 18B Ayat (2) yang berbunyi:

"Negara mengakui dan menghormati kesatuan-kesatuan masyarakat hukum adat beserta hak-hak tradisionalnya sepanjang masih hidup dan sesuai dengan perkembangan masyarakat dan prinsip Negara Kesatuan Republik Indonesia, yang diatur dalam undang-undang."

Bagi hukum progresif, dikatakan hukum yang benar itu bukanlah bunyi undangundang semata, melainkan denyut kehidupan masyarakat. Itulah pasal-pasal yang sebenarnya dari keadilan. Undang-undang seringkali dibuat situasional, tetapi keadilan bersifat kondisional. Situasional artinya berdasarkan pada situasi tertentu, sedangkan kondisional adalah kondisi yang sedang terjadi pada saat kasus itu muncul. ${ }^{14}$

\footnotetext{
${ }^{14}$ Ibid.,hlm.6.
} 
Hukum progresif mengatakan, hakim itu jangan terbelenggu oleh bunyi undangundang yang sifatnya situasional. Hakim harus membuat putusan berdasarkan pada kondisi lokal dan kondisi waktu. Dengan keyakinan dan kemuliaannya hakim harus membuat putusannya sendiri, sehingga rasa keadilan tersebut diterima oleh masyarakat sebagai rasa keadilan, bukan karena kebenaran bunyi undang-undang sesuai dengan peraturan perundang-undangan yang berlaku dikhawatirkan akan timbul konflik diantara kelompok-kelompok masyarakat setempat.

\section{Penutup}

Hakikat dari demokrasi sebenarnya bukan terletak dari cara pemilihan (pencoblosan/pencontrengan), namun hakikat demokrasi adalah partisipasi masyarakat dalam menentukan dan ikut mengambil bagian dalam pemerintahan baik itu dilakukan secara langsung maupun tidak langasung. Jika dilihat dari mekanisme pelaksanaannya sistem noken diangkat dari nilai-nilai filosofis dan pandangan hidup bangsa Indonesia yaitu Pancasila. Sila Ke-empat yakni, "Kerakyatan yang dipimpin oleh hikmat kebijaksaan dalam permusyawaratan/perwakilan”. Karena dalam banyak hal, masyarakat selalu diajak bermusyawarah sebelum memutuskan sesuatu. Sehingga setiap kalangan di dalam masyarakat dapat menyampaikan pendapatnya. Inilah yang menjadi ciri dari demokrasi yang sudah sejak lama hidup di dalam masyarakat di Papua. Kemudian walau secara yuridis sistem noken inkonstitusional dengan Undang-Undang Dasar Negara Republik Indonesia Tahun 1945 (UUD 1945) dan Undang-Undang pemilihan Umum di Indonesia. Namun bagi hukum progresif, sistem noken masih tetap dapat diterapkan dalam pemilihan umum di Indonesia, karena hukum yang benar itu bukanlah bunyi undang-undang semata, melainkan denyut kehidupan masyarakat. Itulah pasal-pasal yang sebenarnya dari keadilan. Undang-undang seringkali dibuat situasional, tetapi keadilan bersifat kondisional. Situasional artinya berdasarkan pada situasi tertentu, sedangkan kondisional adalah kondisi yang sedang terjadi pada saat kasus itu muncul. 


\section{Daftar Pustaka}

\section{Buku-Buku:}

Abdullah, Rozali. (2005). Pelaksanaan Otonomi Luas Dengan Pemilihan Kepala Daerah Secara Langsung, Jakarta: Rajagrafindo Persada.

Busroh, Abu Daud, Abubakar Busroh. (1983). Asas-Asas Hukum Tata Negara, Jakarta: Ghalia Indonesia.

Huda, Ni'matul. (2003). Hukum Tata Negara Indonesia, Jakarta: Raja Grafindo Persada.

Koesnardi, Moh., Bintan R. Saragih. (1998). Ilmu Negara, Jakarta: Gaya Media Pratama.

M.Gaffar, Janedjri. (2013). Demokrasi dan Pemilu di Indonesia, Jakarta: Konstitusi Press (Konpress).

M. Gaffar, Janedjri. (2013). Hukum Pemilu Dalam Yurisprudensi Mahkamah Konstitusi, Jakarta: Konstitusi Press (Konpress).

Mahfud MD, Moh.(2009). Politik Hukum di Indonesia, Edisi Revisi, Jakarta: Rajagrafindo Persada.

Nasution , Bahder Johan. (2011). Negara Hukum dan Hak Azazi Manusia, Bandung: Mandar Maju.

Sudding, Sarifuddin. (2014). Perselingkuhan Hukum dan Politik Dalam Negara Demokrasi, Yogyakarta: Rangkang Education.

\section{Undang-Undang:}

Undang-Undang Dasar Negara Republik Indonesia Tahun 1945.

Undang-Undang Nomor 42 Tahun 2008 Tentang Pemilihan Presiden dan Wakil Umum Presiden.

Putusan Mahkamah Konstitusi Nomor 47-81/PHPU.A-VII/ 2009.

PKPU Nomor 810/PL.02.6-Kpt/06/KPU/IV/2019 tentang Pedoman Pelaksanaan Pemungutan Suara Menggunakan Sistem Noken/Ikat di Papua dalam Pemilu 2019.

\section{Internet:}

http://indonesiasatu.kompas.com/read/2014/08/21/17470521/Sistem.Noken.dan.Demokrasi.

http://m.hukumonline.com/berita/baca/1t5368d22e8f65a/pemerintah-anggap-sistem-nokenbertentangan-dengan-asas-pemilu.

http://budayapapua.wordpress.com/2009/06/12/noken-dan -perempuanpapua/ 